\title{
Non-Hodgkin lymphoma after liver and kidney transplantation in children. Experience from one center
}

\author{
Bożenna Dembowska-Bagińska ${ }^{1, A-F}$, Anna Wakulińska ${ }^{1, B-E}$, Iwona Daniluk ${ }^{1, B, C}$, Joanna Teisseyre ${ }^{2, B, C}$, \\ Irena Jankowska ${ }^{3, B, C}$, Piotr Czubkowski ${ }^{3, B, C}$, Ryszard Grenda ${ }^{4, C, E, F}$, Wioletta Jarmużek ${ }^{4, B, C}$, Wiesława Grajkowska ${ }^{5, B, C, E}$, \\ Jagoda Małdyk ${ }^{6, B, C}$, Piotr Kaliciński ${ }^{2, A, C-F}$ \\ 1 Department of Oncology, Children's Memorial Health Institute, Warszawa, Poland \\ ${ }^{2}$ Department of Pediatric Surgery and Organ Transplantation, Children's Memorial Health Institute, Warszawa, Poland \\ ${ }^{3}$ Department of Gastroenterology, Children's Memorial Health Institute, Warszawa, Poland \\ ${ }^{4}$ Department of Nephrology, Kidney Transplantation and Hypertension, Children's Memorial Health Institute, Warszawa, Poland \\ ${ }^{5}$ Department of Pathology, Children's Memorial Health Institute, Warszawa, Poland \\ ${ }^{6}$ Department of Pathology, Medical University of Warsaw, Poland \\ A - research concept and design; $\mathrm{B}$ - collection and/or assembly of data; $\mathrm{C}$ - data analysis and interpretation; \\ $D$ - writing the article; $E$ - critical revision of the article; $F$ - final approval of the article
}

Address for correspondence

Bożenna Dembowska-Bagińska

E-mail:b.dembowska@ipczd.pl

\section{Funding sources}

None declared

Conflict of interest

None declared

Received on March 26, 2019

Reviewed on July 3, 2019

Accepted on September 25, 2019

Published online on March 10, 2020

Cite as

Dembowska-Bagińska B, Wakulińska A, Daniluk I, et al. Non-Hodgkin lymphoma after liver and kidney transplantation in children. Experience from one center. Adv Clin Exp Med. 2020;29(2):197-202.

doi:10.17219/acem/112605

DOI

10.17219/acem/112605

Copyright

Copyright by Author(s)

This is an article distributed under the terms of the

Creative Commons Attribution 3.0 Unported (CC BY 3.0)

(https://creativecommons.org/licenses/by/3.0/)

\begin{abstract}
Background. Post-transplantation lymphoproliferative disorder (PTLD) is a complication of organ transplantation and a life-threatening condition. Children who underwent organ transplantation are at risk of developing lymphoproliferative disorders and, among them, non-Hodgkin lymphoma (NHL) is the most serious.
\end{abstract}

Objectives. The objective of this study was to describe the clinical course of NHL after liver and kidney transplantation.

Material and methods. Retrospective analysis of medical records of children who underwent liver/kidney transplantation and developed NHL.

Results. Nine children were identified, all girls, 6 after liver and 3 after kidney transplantations. Age at transplantation ranged from 1 year to 13 years (median: 4 years), while age at lymphoma diagnosis from 4 to 17 years (median: 12 years). Time from transplantation to lymphoma diagnosis ranged from 7 months to 12 years (median: 9 years). All but 1 patient developed mature B-cell lymphoma, 4 children - diffuse large B-cell lymphoma (DLBCL), 2 children - Burkitt's lymphoma, 1 child - mature B-cell leukemia, 1 child - Burkitt-like lymphoma, while 1 patient was diagnosed with T-cell lymphoblastic lymphoma. High levels of Epstein-Barr virus (EBV) DNA were found in blood of 3 patients, and EBV in tissue samples was detected in 4 patients. Six patients presented with stage III and 2 with stage IV disease. Two patients had graft involvement. Three children received chemotherapy according to R-CHOP, 3 LMB protocol (2 with addition of rituximab), while 1 received $C H O P$ and 5 courses of COP. T-cell lymphoma patient was treated with Euro- $L B$ protocol. Six out of 8 treated patients are alive with a median follow-up of 6 years. Two children died from disease progression during treatment and 1 from cerebral herniation before starting therapy. All patients experienced at least 1 toxic episode of grade 3 and 4 according to Common Toxicity Criteria Adverse Event (CTCAE). Complications of chemotherapy were manageable and there were no transplanted organ failures.

Conclusions. Our study provides further data on the treatment and outcome of monomorphic PTLD and indicates that it is feasible to treat solid organ recipients with multiagent chemotherapy.

Key words: children, PTLD, non-Hodgkin lymphomas, post-transplantation lymphoproliferative disorders 


\section{Introduction}

Post-transplantation lymphoproliferative disorders (PTLD) are one of the most severe complications of organ transplantation in children and adults. Post-transplantation lymphoproliferative disorders is a life-threatening condition and the cause of mortality and morbidity in this group of patients. It may cause graft loss. In the 2016 World Health Organization (WHO) classification revision of lymphoid neoplasms, 6 types of PTLD are distinguished: from the most benign, non-destructive lymphoplasmacytic to polymorphic destructive proliferations which do not yet fulfill lymphoma criteria, and the last 2 types include monomorphic PTLD with histopathological features of non-Hodgkin lymphoma (NHL) and rarely occurring classical Hodgkin lymphoma. ${ }^{1}$ Children who underwent solid organ transplantation are at significant risk of developing lymphoproliferative disorders and, among them, NHL is the most serious. ${ }^{2}$ Treatment of such patients is challenging with regard to the choice of chemotherapy protocol and management of chemotherapy-related complications in an already vulnerable population. We report herein a retrospective analysis of 9 patients with posttransplant NHL who were treated in our center, the only one in Poland where kidney and liver transplantations in children are performed.

\section{Material and methods}

Among 1,518 patients who underwent liver (618 patients) or kidney (900 patients) transplantations in our institution between 1984 and 2015, 9 patients were diagnosed with monomorphic PTLD NHL. Medical records of these patients were reviewed and analyzed for the following data: sex, age at transplantation and NHL diagnosis, type of organ transplanted, indication for transplantation, EpsteinBarr virus (EBV) status at the time of transplantation and NHL diagnosis, type of immunosuppression, previous history of PTLD, time from transplantation to NHL, NHL subtype, disease stage, graft organ involvement by lymphoma, treatment, its toxicity, and outcome.

The diagnosis of lymphoma was based on a histological and immunohistochemical examination of tumor tissue and was classified according to WHO classification. Non-Hodgkin lymphoma was staged according to Revised International Pediatric Non-Hodgkin Lymphoma Staging System. ${ }^{3}$ Epstein-Barr virus DNA has been quantified in the routine follow-up of immunosuppressed transplanted patients to detect EBV reactivation or primary infection. It was performed with polymerase chain reaction (PCR) in serum or whole blood and in the biopsy sample of a tumor using EBV-encoded RNA in situ hybridization. Treatment toxicity was graded according to Common Toxicity Criteria for Adverse Events v. 4 (CTCAE) and reported after each chemotherapy cycle. ${ }^{4}$
Due to small number of heterogenous patients, no statistical analyses including regression analysis were performed.

\section{Results}

All patients were girls, aged from 1 to 13 years (median 4 years) at the time of transplantation and 4 to 17 years (median: 12 years) at lymphoma diagnosis. Six of them (1\%) underwent liver and $3(0.33 \%)$ kidney transplantation. Indications to liver transplantation were biliary atresia in 5 patients and acute liver failure from mushroom poisoning in 1. Kidney transplantations were performed for end-stage kidney disease.

Initial post-transplantation immunosuppression consisted of tacrolimus and prednisone (3 patients); tacrolimus, cyclosporine, mycophenolate mofetil, and prednisone (1 patient); cyclosporine and rapamycin (1 patient); cyclosporin, rapamycin, azathioprine and prednisone (1 patient); cyclosporin, rapamycin, mycophenolate mofetil, and prednisone (1 patient); or rapamycin, mycophenolate mofetil and prednisone (1 patient). One patient received induction with anti CD25 antibody (daclizumab) in addition to tacrolimus, mycophenolate mofetil and prednisone. Since none of the patients experienced severe acute organ rejection episodes, there was no use for anti-thymocyte globulin.

Time from transplantation to lymphoma diagnosis ranged from 7 months to 12 years (median: 9 years). One child 5 years after liver transplantation and 4 years prior to lymphoma diagnosis experienced polymorphic PTLD episode, which was successfully managed with the reduction of immunosuppression and 2 courses of rituximab $\left(375 \mathrm{mg} / \mathrm{m}^{2}\right)$.

All but 1 patient developed mature B-cell lymphoma, 4 children (50\%) - DLBCL, 2 - Burkitt's lymphoma, 1 - mature B-cell leukemia, 1 - Burkitt-like lymphoma, and 1 patient was diagnosed with T-cell lymphoblastic lymphoma. Very high numbers of EBV DNA copies $(53,000 / \mathrm{mL}, 105,000 / \mathrm{mL}$ and $150,000 / \mathrm{mL}$, respectively) were found in peripheral blood and serum of 3 patients at the onset of lymphoma - PTLD, whereas EBV was detected in tissue samples in 4 patients with mature B-cell lymphoma. Eight patients had advanced disease, 6 of them presented with stage III and 2 with stage IV (1 lymphoma/ leukemia, and 1 patient with massive central nervous system (CNS) disease (Fig. 1). Two patients presented with lymphoma graft involvement - of kidney and liver.

Clinical characteristics of patients with NHL following liver/kidney transplantation are presented in Table 1.

Reduction of immunosuppression (RIS) or discontinuation was undertaken in all 9 patients at PTLD diagnosis without satisfactory response. One girl received 2 courses of rituximab, after which disease progression was observed. Two out of 4 children with DLBCL received 6 courses of R-CHOP. One was treated with group C lymphoma malignancy B-cell (LMB) protocol. Three patients 

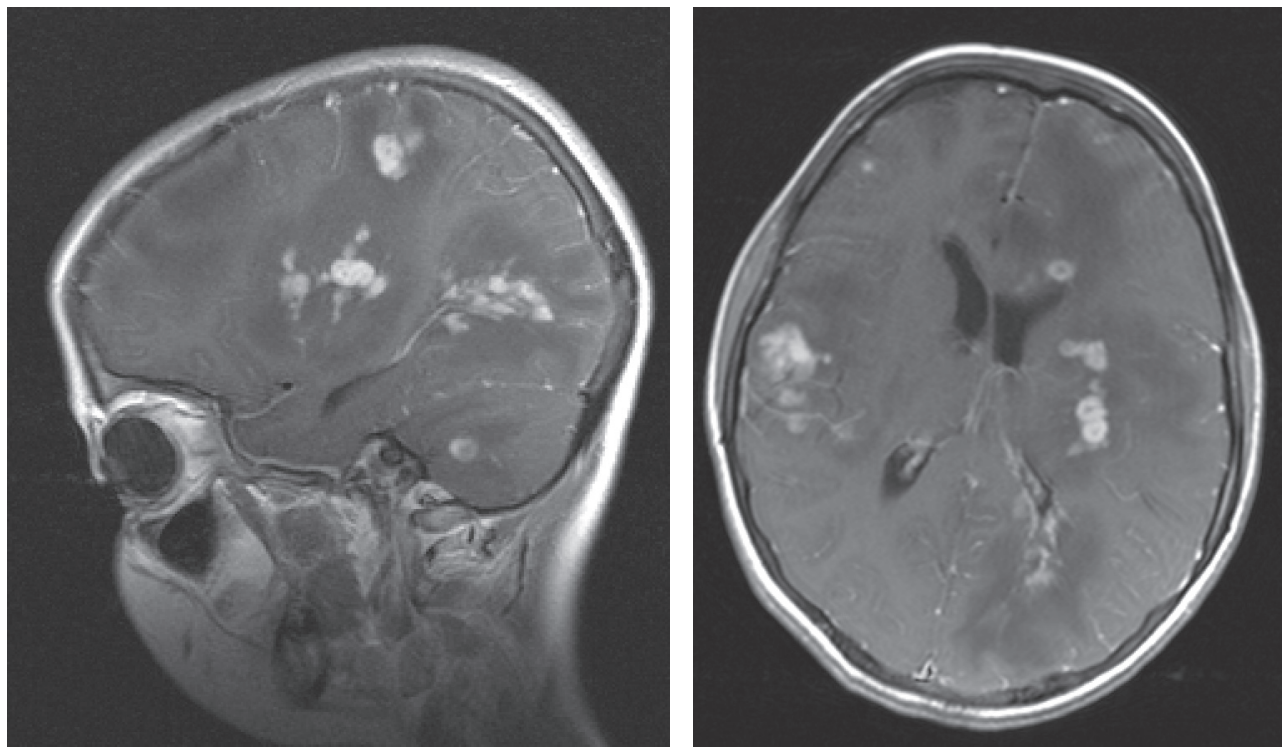

Fig. 1. CT scans showing numerous enhancing lesions throughout both cerebral hemispheres - patient No. 2

Table 1. Patients' characteristics

\begin{tabular}{|c|c|c|c|c|c|c|c|}
\hline $\begin{array}{l}\text { Patient } \\
\text { No. }\end{array}$ & $\begin{array}{c}\text { Age [years] } \\
\text { at transplantation/ } \\
\text { year } \\
\text { of transplantation }\end{array}$ & $\begin{array}{l}\text { Indication for } \\
\text { transplantation/ } \\
\text { organ/donor }\end{array}$ & $\begin{array}{c}\text { Age [years] } \\
\text { at NHL } \\
\text { diagnosis/year } \\
\text { of NHL diagnosis }\end{array}$ & $\begin{array}{l}\text { NHL type stage/ } \\
\text { primary site }\end{array}$ & $\begin{array}{l}\text { EBV status: } \\
\text { serum/tumor } \\
\text { (copies/mcg } \\
\text { DNA in serum) }\end{array}$ & $\begin{array}{l}\text { Treatment } \\
\text { protocol }\end{array}$ & $\begin{array}{l}\text { Outcome } \\
\text { survival time } \\
\text { from NHL } \\
\text { diagnosis }\end{array}$ \\
\hline 1 & $\begin{array}{c}2 \\
1998\end{array}$ & $\begin{array}{l}\text { biliary atresia/ } \\
\text { liver/living donor }\end{array}$ & $\begin{array}{c}11 \\
2007\end{array}$ & $\begin{array}{l}\text { Burkitt's lymphoma/III } \\
\text { lymph nodes, abdomen/ } \\
\text { mediastinum, orbital mass }\end{array}$ & $\begin{array}{c}+/- \\
(10,823)\end{array}$ & $\begin{array}{l}\mathrm{LMB} 89+\mathrm{R} \\
\text { AHSCT }\end{array}$ & $\begin{array}{l}\text { ADF } \\
11 \text { years }\end{array}$ \\
\hline 2 & $\begin{array}{c}8 \\
1998\end{array}$ & $\begin{array}{l}\text { biliary atresia/ } \\
\text { liver/living donor }\end{array}$ & $\begin{array}{c}17 \\
2007\end{array}$ & $\begin{array}{c}\mathrm{DLBCL} / \mathrm{IV} \\
\mathrm{CNS} \text {, lungs, spleen }\end{array}$ & $\begin{array}{c}+/+ \\
(1,532)\end{array}$ & prednisone & $\begin{array}{l}\text { died from } \\
\text { cerebral } \\
\text { herniation } \\
3 \text { days }\end{array}$ \\
\hline 3 & $\begin{array}{c}4 \\
2001\end{array}$ & $\begin{array}{l}\text { biliary atresia/ } \\
\text { liver/living donor }\end{array}$ & $\begin{array}{c}4 \\
2001\end{array}$ & $\begin{array}{c}\text { DLBCL plasmoblastic } \\
\text { type/III } \\
\text { lymph nodes - abdomen }\end{array}$ & $-1+$ & $\begin{array}{l}\text { LMB chemo- } \\
\text { therapy dose } \\
\text { reduction }\end{array}$ & $\begin{array}{l}\text { died from PD } \\
11 \text { months }\end{array}$ \\
\hline 4 & $\begin{array}{c}3 \\
2002\end{array}$ & $\begin{array}{l}\text { biliary atresia/ } \\
\text { liver/deceased }\end{array}$ & $\begin{array}{c}15 \\
2014\end{array}$ & $\begin{array}{l}\mathrm{DLBCL} / \mathrm{III} \\
\text { bowel }\end{array}$ & $\begin{array}{c}+/+ \\
(400)\end{array}$ & $\mathrm{R}-\mathrm{CHOP}$ & $\begin{array}{l}\text { ADF } \\
4 \text { years }\end{array}$ \\
\hline 5 & $\begin{array}{c}1 \\
2002\end{array}$ & $\begin{array}{l}\text { biliary atresia/ } \\
\text { liver/living donor }\end{array}$ & $\begin{array}{c}11 \\
2012\end{array}$ & $\begin{array}{l}\text { Burkitt-like lymphoma/III } \\
\text { oral cavity, tonsils } \\
\text { submandibular and } \\
\text { mediastinal lymph nodes }\end{array}$ & $-1-$ & $\mathrm{R}-\mathrm{CHOP}$ & $\begin{array}{l}\text { ADF } \\
6 \text { years }\end{array}$ \\
\hline 6 & $\begin{array}{c}13 \\
2007\end{array}$ & $\begin{array}{l}\text { mushroom } \\
\text { poisoning/liver/ } \\
\text { deceased }\end{array}$ & $\begin{array}{c}16 \\
2010\end{array}$ & $\begin{array}{l}\text { TLBL/III } \\
\text { infiltration of lungs alone }\end{array}$ & $-1-$ & EURO LB & $\begin{array}{c}\text { ADF } \\
8 \text { years }\end{array}$ \\
\hline 7 & $\begin{array}{c}7 \\
2005\end{array}$ & $\begin{array}{l}\text { end-stage kidney } \\
\text { disease/kidney/ } \\
\text { deceased }\end{array}$ & $\begin{array}{c}16 \\
2014\end{array}$ & $\begin{array}{l}\mathrm{DLBCL} / \mathrm{III} \text { lymph } \\
\text { nodes mediastinum/ } \\
\text { retroperitoneum }\end{array}$ & $-1-$ & $\mathrm{R}-\mathrm{CHOP}$ & $\begin{array}{l}\text { ADF } \\
4 \text { years and } \\
2 \text { months }\end{array}$ \\
\hline 8 & $\begin{array}{c}4 \\
2011\end{array}$ & $\begin{array}{c}\text { end-stage kidney } \\
\text { disease/kidney/ } \\
\text { deceased }\end{array}$ & $\begin{array}{c}8 \\
2015\end{array}$ & $\begin{array}{c}\text { mature B-cell leukemia } \\
\text { bone marrow, lymph } \\
\text { nodes/abdomen }\end{array}$ & $\begin{array}{c}+/+ \\
(53,950,000)\end{array}$ & LMB 2001+R & died from PD \\
\hline 9 & $\begin{array}{c}5 \\
2010\end{array}$ & $\begin{array}{l}\text { end-stage kidney } \\
\text { disease/kidney/ } \\
\text { deceased }\end{array}$ & $\begin{array}{c}11 \\
2016\end{array}$ & $\begin{array}{l}\text { Burkitt's lymphoma/II } \\
\text { neck, supraclavicular, } \\
\text { mediastinal lymph nodes }\end{array}$ & $\begin{array}{c}+/+ \\
(105,000)\end{array}$ & $\begin{array}{l}1 \text { course } \\
\text { of } \mathrm{CHOP} \\
5 \text { courses } \\
\text { of COP }\end{array}$ & $\begin{array}{c}\text { ADF } \\
2 \text { years }\end{array}$ \\
\hline
\end{tabular}

DLBCL - diffuse large B-cell lymphoma; TLBL - T-cell lymphoblastic lymphoma; LMB - lymphoma malignancy B-cell; EURO-LB - European Intergroup EURO-LBO2 protocol; CHOP - cytoxan, vincristine, doxorubicin, prednisone; ADF - alive disease-free; PD - progressive disease; AHSCT - autologous hematopoetic stem cell transplantation; CNS - central nervous system.

with Burkitt's lymphoma received treatment according to $\mathrm{LMB}$ and 1 patient received 1 course of $\mathrm{CHOP}$ followed by 5 courses of COP chemotherapy. A T-cell lymphoma patient was treated according to European Intergroup EURO-LB02 protocol. All but 2 patients received chemotherapy without modifications of anticancer drugs 
dosages. Six out of 9 patients are alive and disease-free after 2-11 years (median follow-up of 6 years). Among them, 1 girl with Burkitt's lymphoma who did not achieve CR during LMB protocol underwent high-dose chemotherapy followed by autologous hematopoetic stem cell rescue. To date, no other PTLD episodes have been observed in this group.

Two children died from disease progression during treatment. One was a girl with stage III DLBCL, who was our first patient with monomorphic PTLD after liver transplantation. Her treatment started with RIS followed by 2 courses of rituximab. Disease progression was observed and LMB protocol applied with reduction of drugs doses. The other deceased patient was a girl with mature B-cell leukemia after kidney transplantation. At PTLD diagnosis, she presented with very high EBV viral load in serum and tumor tissue. Transient response to chemotherapy according to LMB protocol for group $\mathrm{C}$ was achieved, then massive progression of leukemia was observed. The $3^{\text {rd }}$ deceased patient was a liver recipient with rapidly progressing CNS lymphoma who died from cerebral herniation before treatment was commenced. All patients experienced at least 1 episode of grade 3 and 4 CTCAE hematologic toxicities episodes during treatment. Grade 3 and 4 hematological toxicity with severe neutropenia and thrombocytopenia was noted in patients following COPADM and CYVE courses. Patients who received rituximab did not experience severe infectious complications and did not require immunoglobulin substitution.

All patients experienced at least 1 episode of neutropenic fever, 6 of them more than once. Oral mucositis was the second most common toxicity. There were 6 grade 3 and 4 episodes after COPADM chemotherapy attributed to methotrexate and doxorubicin. One patient after $\mathrm{R}-\mathrm{CHOP}$ protocol developed deep vein thrombosis. There were no episodes of transplanted organ failure and no rejections. No unexpected adverse events were observed. All complications were manageable. There were no treatment-related sepsis nor deaths.

\section{Discussion}

Children who underwent solid organ transplantation have a higher risk of cancer as compared to the general population. In a study by Yanik et al., among 17,958 pediatric recipients cancer was diagnosed in 392 patients, of which 71\% developed NHL. The incidence rate of NHL in this study was $1.3 \%$ for both liver and kidney recipients. ${ }^{5}$ Others report that the incidence of PTLD varies between $5 \%$ and $15 \%$ for liver and between $1.9 \%$ and $10 \%$ for kidney-transplanted children. ${ }^{6-10}$ In our patient group, the incidence rate of NHL for liver and kidney recipients was $0.97 \%$ and $0.33 \%$, respectively, which is in line with data presented by Yanik et al.

In general, the incidence of PTLD in children is lower for kidney than for liver transplantations, ${ }^{11}$ which was also documented in our study. It is most likely that the higher incidence of PTLD in children after liver transplantation, as compared to kidney transplantation, is due to the younger age of liver recipients and their seronegativity to EBV at the time of transplantation, which left them susceptible to primary EBV infection.

Post-transplantation lymphoproliferative disorder in immunocompromised, T-cell-impaired transplant recipients is strongly associated with EBV, which is reflected by EBV viral load in peripheral blood. In our series, 5 out of 9 patients presented with elevated levels of EBV; however, it was of significant value in only 3 patients. The post-solid-organ transplantation EBV-related PTLD appears to be bimodal, with first peak occurring during the first year from transplantation, then years later. ${ }^{12}$

Only 1 of our patients developed PTLD - DLBCL within 1 year after liver transplantation and the child was negative for EBV. For the remaining 7 patients, PTLD - DLBCL development occurred during the $1^{\text {st }}$ decade and for 1 patient 12 years after transplantation. In the study by Yanik et al, which included 278 NHL patients, the median time from transplantation to NHL diagnosis was 1 year and 6 months, which was different than in the studies of other authors and in our data. Her data seems most reliable considering the large number of presented patients.

It is postulated that patients with late onset of PTLD have a more aggressive disease and worse outcome, ${ }^{13}$ whereas in our series only 1 patient had an early onset of lymphoma and presented an unfavorable course of disease.

Among transplant recipients diagnosed with NHL, more than 75\% develop mature B-cell lymphoma, of which 65\% are DLBCL and $9 \% \mathrm{BL}$, opposite than in general pediatric population. A few PTLDs are of T-cell origin. ${ }^{5}$ This was also demonstrated in our patients; all but 1 had a diagnosis of mature B-cell lymphoma, though the distribution of DLBCL and BL was similar. Most interestingly, 1 of our patients developed primary pulmonary T-cell lymphoma 3 years after liver transplantation. Primary pulmonary lymphoma is a very rare condition and accounts for less than $1 \%$ of all NHL cases, of which $80 \%$ are of B-cell origin. To the best of our knowledge, very few such cases have been published, none in the pediatric population. ${ }^{14}$

Post-transplantation lymphoproliferative disorder can affect many organs, presenting with non-specific clinical features and extranodal involvement. ${ }^{15}$ It has been shown in some studies that it has a propensity to occur in the anatomic region of the transplanted organ. ${ }^{16,17}$ In our series, 6 patients had lymph node involvement below and above diaphragm, whereas the remaining 3 had extranodal disease involving the lungs, CNS and intestine. In the general population, about $70 \%$ of children with NHL present with advanced stage III and IV disease, which is also true for monomorphic PTLD. ${ }^{18,19}$ All of our children had advanced disease, of whom 1 had extranodal massive CNS involvement and another lymphoma/leukemia.

Optimal treatment of PTLD has not yet been established, though the National Comprehensive Cancer 
Network (NCCN) or other clinical practice guidelines have been published. ${ }^{20-22}$ First-line management of EBVPTLD involves reducing immunosuppression, and even its discontinuation, which may result in PTLD remission. This particularly concerns patients with less aggressive disease morphology. Rituximab, although unauthorized, is in practice a standard first-line treatment for EBV-PTLD with responses reported in the $44-66 \%$ range. ${ }^{23,24}$ There is still a substantial number of patients who will fail to respond to rituximab, relapse or present with EBV-negative PTLD, for whom the usual treatment is multiagent chemotherapy with standard treatment protocols specific for lymphoma type. Treatment of adult patients is usually based on chemoimmunotherapy consisting of rituximab and CHOP regimen. ${ }^{25-27}$ Gross et al. in a phase II trial demonstrated that rituximab with low-dose cyclophosphamide and prednisone is safe and effective in pediatric patients with EBV, CD20 (+) PTLD. After 2 years, the overall survival rate was $85 \% .{ }^{28}$ Same efficacy of rituximab with low-dose chemotherapy was confirmed by Gupta et al. and it is a preferable method of treatment. ${ }^{29}$

Our approach was more aggressive in terms of chemotherapy.

The justification for choosing regular chemotherapy regimens was based on the patient's EBV and clinical status, disease severity as well as the time when PTLD was diagnosed. Moreover, treatment failure of our first PTLD patient who did not respond to RIS, had progressive disease after 2 rituximab courses and received unsuccessful chemotherapy with reduced doses of anticancer drugs influenced our decision to treat the following monomorphic PTLD according to current lymphoma protocol, though each case is usually considered individually.

Long-term outcome of monomorphic PTLD in children is estimated to be over $80 \%{ }^{11,30}$ Patients with CNS and bone marrow involvement have inferior outcomes as compared to patients with lower disease stage as NHL in general population. ${ }^{31}$ This was also observed in our study. In our series, 6 out of 8 treated patients are alive with a long-term follow-up from 2 to 11 years (median: 4 years). To date, none of them neither relapsed nor experienced another PTLD episode. We included in our analyses an untreated patient to demonstrate that PTLD involving the central nervous system can have a fulminant, fatal course not giving enough time for implementing proper treatment.

It is suggested that patients with EBV-negative tumors fare worse than EBV-positive ones. ${ }^{10}$ In our study, 4 children with EBV-negative tumors are alive.

Children undergoing treatment of NHL experience chemotherapy-related complications. The most common are hematologic toxicities, neutropenic fever and mucositis. Of special concern are patients with PTLD in whom chemotherapy complications may cause graft failure. ${ }^{30}$ During the whole treatment process, none of our patients had any kind of graft insufficiency. Toxicity episodes were as expected following NHL chemotherapy and were all manageable. There were no episodes requiring treatment in the intensive care unit. Moreover, treatment with rituximab did not add adversely to infectious complications.

Our study provides further data on the treatment and outcome of monomorphic PTLD and indicates that it is feasible to treat children with multiagent chemotherapy after solid organ transplantation. The authors acknowledge the limitations of the study, its retrospective character and small number of patients from one institution. However, the presented study comes from a single pediatric-only national transplant center with a large number of performed liver and kidney transplantations, established protocols and multidisciplinary approach, thus making the data reliable for the pediatric population.

\section{ORCID iDs}

Bożenna Dembowska-Bagińska

(D) https://orcid.org/0000-0002-3845-5380

Anna Wakulińska (D) https://orcid.org/0000-0002-2561-0636 Iwona Daniluk (D) https://orcid.org/0000-0003-3511-2355 Joanna Teisseyre (D) https://orcid.org/0000-0002-3706-9429 Irena Jankowska (1) https://orcid.org/0000-0001-6847-9570 Piotr Czubkowski (D) https://orcid.org/0000-0002-0332-5703 Ryszard Grenda (D) https://orcid.org/0000-0002-6814-6589 Wioletta Jarmużek (D) https://orcid.org/0000-0002-9929-7486 Wiesława Grajkowska (D) https://orcid.org/0000-0001-8318-5781 Jagoda Małdyk (D) https://orcid.org/0000-0002-4598-204X Piotr Kaliciński (D) https://orcid.org/0000-0003-0555-2229

\section{References}

1. Swerdlow SH, Campo E, Pileri SA, et al. The 2016 revision of the World Health Organization classification of lymphoid neoplasms. Blood. 2016;127(20):2375-2390.

2. Yanik EL, Smith JM, Shiels MS, et al. Cancer risk among pediatric solid organ transplant recipients in the United States. Pediatrics. 2017; 139(5):e20163893.

3. Rosolen A, Perkins SL, Pinkerton CR, et al. Revised International Pediatric Non-Hodgkin Lymphoma Staging System. J Clin Oncol. 2015; 33(18):2112-2118.

4. The National Cancer Institute issued the Common Terminology Criteria for Adverse Events (CTCAE) version 4.0 on May 29, 2009.

5. Yanik EL, Shiels MS, Smith JM, et al. Contribution of solid organ transplant recipients to the pediatric non-Hodgkin lymphoma burden in the United States. Cancer. 2017;123(23):4663-4671.

6. Fernández MC, Bes D, De Dávila M, et al. Post-transplant lymphoproliferative disorder after pediatric liver transplantation: Characteristics and outcome. Pediatr Transplant. 2009;13(3):307-310.

7. Jeon TY, Kim JH, Eo H, et al. Posttransplantation lymphoproliferative disorder in children: Manifestations in hematopoietic cell recipients in comparison with liver recipients. Radiology. 2010;257(2):490-497.

8. D'Alessandro AM, Knechtle SJ, Chin LT, et al. Liver transplantation in pediatric patients: Twenty years of experience at the University of Wisconsin. Pediatr Transplant, 2007;11(6):661-670.

9. Jain A, Nalesnik M, Reyes J, et al. Posttransplant lymphoproliferative disorders in liver transplantation: A 20-year experience. Ann Surg. 2002;236(4):429-436.

10. Taylor AL, Marcus R, Bradley JA. Post-transplant lymphoproliferative disorders (PTLD) after solid organ transplantation. Crit Rev Oncol Hematol. 2005;56(1):155-167.

11. Mynarek M, Schober T, Behrends U, Maecker-Kolhoff B. Posttransplant lymphoproliferative disease after pediatric solid organ transplantation. Clin Dev Immunol. 2013;2013:814973.

12. Quinlan SC, Pfeiffer RM, Morton LM, et al. Risk factors for early-onset and late-onset post-transplant lymphoproliferative disorder in kidney recipients in the United States. Am J Hematol. 2011;86(2):206-209. 
13. Halula SE, Leino DG, Patel MN, Racadio J, Lungren MP. Isolated upper extremity posttransplant lymphoproliferative disorder in a child. Case Rep Radiol. 2015;2015:813989.

14. Zhang $S$, Liang $B$, Jiang $S$. Primary pulmonary peripheral T-cell lymphoma: A case report and review of the literature. Thorac Cancer. 2014;5(1):104-107.

15. Al-Mansour Z, Nelson BP, Evens AM, Nelson MD. Post-transplant lymphoproliferative disease (PTLD): Risk factors, diagnosis, and current treatment strategies. Curr Hematol Malig Rep. 2013;8(3):173-183.

16. Wilde GE, Moore DJ, Bellah RD. Posttransplantation lymphoproliferative disorder in pediatric recipients of solid organ transplants: Timing and location of disease. AJR Am J Roentgenol. 2005;185(5): 1335-1341.

17. Donnelly LF, Frush DP, Marshall KW, White KS. Lymphoproliferative disorders: CT findings in immunocompromised children. AJR Am J Roentgenol. 1998;171(3):725-731.

18. Cairo MS, Sposto R, Gerrard M, et al. Advanced stage, increased lactate dehydrogenase, and primary site, but not adolescent age ( $\geq 15$ years), are associated with an increased risk of treatment failure in children and adolescents with mature B-cell non-Hodgkin's lymphoma: Results of the FAB LMB 96 Study. J Clin Oncol. 2012;30(4): 387-393.

19. Patte $C$, Auperin A, Gerrard M, et al. Results of the randomized international FAB/LMB96 trial for intermediate risk B-cell non-Hodgkin lymphoma in children and adolescents: It is possible to reduce treatment for the early responding patients. Blood. 2007;109(7):2773-2780.

20. NCCN clinical practice guidelines in oncology. https://oncolife.com. ua/doc/nccn/B-Cell_Lymphomas.pdf. Accessed March 21, 2019.

21. EBV Work Group, Cincinnati Children's Hospital Medical Center. Evidence-based clinical care guideline for Management of EBVAssociated Post-Transplant Lymphoproliferative Disease in Solid Organ Transplant. Guideline 18, pages 1-18, June, 2011: http://www cincinnatichildrens.org/svc/alpha/h/health-policy/guidelines.htm/. Accessed March 21, 2019.
22. Parker A, Bowles K, Bradley J, et al. Diagnosis of post-transplant lymphoproliferative disorder in solid organ transplant recipients: $\mathrm{BCSH}$ and BTS Guidelines. Br J Haematol. 2010;149(5):675-692.

23. Choquet $S$, Leblond $V$, Herbrecht $R$, et al. Efficacy and safety of rituximab in B-cell post-transplantation lymphoproliferative disorders: Results of a prospective multicenter phase 2 study. Blood. 2006; 107(8):3053-3057.

24. Oertel SH, Verschuurenb E, Reinkea P, et al. Effect of anti-CD20 antibody rituximab in patients with post-transplant lymphoproliferative disorder (PTLD). Am J Transplant. 2005;5(12):2901-2906.

25. Trappe R, Oertel S, Leblond V, et al. Sequential treatment with rituximab followed by CHOP chemotherapy in adult B-cell post-transplant lymphoproliferative disorder (PTLD): The prospective international multicentre phase 2 PTLD-1 trial. Lancet Oncol. 2012;13(2):196-206.

26. Trappe R, Dierickx D, Zimmermann H, et al. Response to Rituximab induction is a predictive marker in B-cell post-transplant lymphoproliferative disorder and allows successful stratification into rituximab or R-chop consolidation in an international, prospective, multicenter phase II trial. J Clin Oncol. 2017;35(5):536-543.

27. Zimmermann $\mathrm{H}$, Trappe RU. Therapeutic options in post-transplant lymphoproliferative disorders. Ther Adv Hematol. 2011;2(6):393-407.

28. Gross TG, Orjuela MA, Perkins SL, et al. Low-dose chemotherapy and rituximab for posttransplant lymphoproliferative disease (PTLD): A Children's Oncology Group Report. Am J Transplant. 2012;12(11): 3069-3075.

29. Gupta S, Fricker FJ, González-Peralta RP, Slayton WB, Schuler PM, Dharnidharka VR. Post-transplant lymphoproliferative disorder in children: Recent outcomes and response to dual rituximab/low-dose chemotherapy combination. Pediatr Transplant. 2010;14(7):896-902.

30. Bishnoi R, Bajwa R, Franke AJ, et al. Post-transplant lymphoproliferative disorder (PTLD): Single institutional experience of 141 patients. Exp Hematol Oncol. 2017;6:26.

31. Maecker B, Jack T, Zimmermann M, et al. CNS or bone marrow involvement as risk factors for poor survival in post-transplantation lymphoproliferative disorders in children after solid organ transplantation. Clin Oncol 2007;25(31):4902-4949. 